\title{
Reducing geo-disasters for improving the relationships between geoenvironment and society
}

Fawu Wang

What is the journal of Geoenvironmental Disasters? Geoenvironmental Disasters is an international journal that provides a focus on multi-disciplinary applied and fundamental research and the societal impacts related to geoenvironmental disasters triggered by various types of hazards, e.g. earthquakes, volcanic activity, landslides, tsunamis, intensive erosion, sinkhole and hydrometeorological events. Disasters are defined here as dynamic forces which can change the Earth pervasively, rapidly, or abruptly, and which can generate lasting effects on the natural and built environments.

The integrated study of Geoenvironmental Disasters is an emerging and composite field of research interfacing with areas traditionally within civil engineering, earth sciences, atmospheric sciences and the life sciences. It focuses on the interactions within and between the Earth's ground, air and water environments, all of which are affected by climate, geological and morphological processes, biological and ecological cycles, and human activities.

The journal presents research papers, rapid, preliminary reports of recent geoenvironmental disasters, review papers and technical reports of various geoenvironmental disasterrelated case studies. The journal aims for rapid publication of research papers at a robust scientific level. The journal welcomes proposals for special issues reflecting the trends in techniques to investigate, monitor and reduce the impacts of geoenvironmental disaster and monothematic issues. Researchers and practitioners are encouraged to submit original, unpublished contributions.

The research topics covered by the journal include, but are not limited to, the following fields:
- Natural hazards as source of geoenvironmental disasters

- Understanding the impacts of geoenvironmental disasters

- Community geoenvironmental disaster mitigation, preparedness, response and recovery from geoenvironmental disaster events

- Development of analytical instruments, modelling and methods for geoenvironmental disaster reduction

- New proxies and laboratory techniques for geoenvironmental disaster risk reduction

- Remote sensing tools and techniques for geoenvironmental disaster observation and mitigation

- GIS techniques for geoenvironmental disaster management

- Impact of geoenvironmental disasters on urban and rural infrastructures

- Geoenvironmental disaster database and knowledge-sharing

- Climate and environmental changes and geoenvironmental disaster mitigation

- Management of geoenvironmental disasters in a low-population environment

- Anthropogenic controls on geoenvironmental disasters

- Social and economic impacts of geoenvironmental disasters

- Resilience of environmental systems to global change and extreme events

- Impact of geoenvironmental disasters on cultural and environmental heritage and conservation areas

- Geoenvironmental disaster adaptation and risk perception

Correspondence: wangfw@riko.shimane-u.ac.jp

Department of Geoscience, Shimane University, Matsue, Japan 
- Engineering designs for geoenvironmental disaster mitigation

- Low-cost, environmentally- friendly and sustainable geoenvironmental disaster mitigation practices

- Forecasting and early warning of geoenvironmental disaster events

- Theoretical aspects of geoenvironmental disaster studies and forecasting

- Other important new applications or theories regarding geoenvironmental

\section{Who is the ICGdR?}

Geoenvironmental Disasters is an official journal of the International Consortium on Geo-disaster Reduction (ICGdR). The ICGdR is an international non-governmental and non-profit scientific organization legally registered as non-profit as of 2013, according to Japanese law, in the Shimane Prefecture. The ICGdR contributes to a safe and secured social and natural environment by promoting the reduction of disasters triggered by geological and geophysical phenomena on the Earth. The domicile of the ICGdR is Matsue City, Shimane Prefecture in Japan.

In the past decades, geo-disasters triggered by typhoon, landslide sinkhole, debris flow, earthquake, tsunami, and volcanic eruption frequently occurred in Asia. These disasters caused huge damage of infrastructures, the natural environment and great loss of human life and property. As disasters are serious threats to human society, the reduction of geo-disasters have become urgent and critical issues for life safety and economic development.

Before the official establishment of the ICGdR, the core members conducted preparatory activities for 10 years. In 2003 the first symposium was held at Kanazawa University, Japan for the mitigation of geo-disasters in the areas around the Japan Sea. This pioneering event drew attention of researchers and engineers from China, Korea and Japan. The second, third and fourth symposia were also held at Kanazawa University. Then, the fifth and sixth symposia were held at Chang'an University and Kunming University of Science and Technology in China, respectively. In 2009 the symposium was renamed as "The International Symposium on Mitigation of Geo-disasters in Asia" in order to include more countries and to cover a larger area. The seventh event was then held in Northeast Forestry University, China. The eighth and ninth symposia were held in National Far-East Technology University, Vladivostok, Russia in 2010, and Universitas Gadjah Mada, Yogyakarta, Indonesia in 2011, respectively. Gradually, the event transitioned from regional to international. In 2012, Shimane University, Japan organized the tenth symposium, and about 100 participants attended this event. During the symposium, a field trip from Sendai, via Hotaka and Kyoto, to Matsue was made to investigate the disasters caused by earthquake, tsunami, volcano, and landslide. To celebrate the tenth anniversary of the symposium, the core members collaborated to publish "The Progress of Geo-disaster Mitigation Technology in Asia" (published by Springer) to show the progress of geo-disaster mitigation technologies in Asia. According to a regional initiative from Asia, the participants, of which most are experts on geo-disaster reductions, had an intent to establish an international consortium on geo-disaster reduction. In May 2013, the organizing meeting of the International Consortium on Geo-disaster Reduction (ICGdR) was held in China Institute of Disaster Prevention, Beijing, China. The legal registration was completed in August 2013 in Matsue, Japan.

In 2013, the eleventh symposium was successfully held in Kathmandu, Nepal. The Nepalese Prime Minister (the Chairman of the Interim Council of Ministers) inaugurated this event and gave great concern to geo-disaster reduction in the region. Based on the success of the last ten symposia, the core members of ICGdR have agreed to open the symposium to now include the whole world, as well as Asia. At this time the symposium was officially renamed the "International Symposium on Geo-disaster Reduction". The twelfth event will be held in Fullerton, California, USA in 2014. In addition to the activity of symposium, the first training course was organized by National Taiwan University in Taiwan, in August 2013. The course focused on advanced technology of hazard assessment and mitigation of landslide and debris flow through means of lectures and practices. The participants, a total 35 persons from 16 countries, expressed strong praise for this course and stated their support for future courses of this nature.

With a firm foundation based on past preparatory activities, the ICGdR is devoted to reduction of geo-disasters in human environments and looking forward to benefiting human society in the coming future.

The primary objectives of the ICGdR are to: 1) promote geo-disaster reduction for the benefit of human society and the natural environment, and the creations of capacity development, including education; 2) combine international expertise and coordinate their efforts in geo-disaster reduction, thereby resulting in an effective international organization which will act as a partner in various projects; and, 3) promote regional and global, multidisciplinary activity on geo-disaster reduction.

The primary activities planned include international coordination, international collaborative research, international meetings (e.g., symposium, field trip, lectures, and training courses), database development, and the editing and publication of "Geoenvironmental Disasters"- the official journal of the ICGdR. 
Finally, we hope all people can use the journal as a platform to exchange new findings, ideas, technologies, and methodologies related to the geoenvironmental disaster reduction so that the relationships between the geoenvironment and human society can be improved.

Fawu Wang

The Editor-in-Chief

The Director-General of ICGdR

Project Center on Natural Disaster Reduction, Shimane

University, Japan

Received: 22 July 2014 Accepted: 22 July 2014

2.resed: 22 uly 2014 Accepted: 22 July

doi:10.1186/s40677-014-0003-4

Cite this article as: Wang: Reducing geo-disasters for improving the

relationships between geoenvironment and society. Geoenvironmental

Disasters 2014 1:3.

\section{Submit your manuscript to a SpringerOpen ${ }^{\circ}$ journal and benefit from:}

- Convenient online submission

- Rigorous peer review

- Immediate publication on acceptance

- Open access: articles freely available online

- High visibility within the field

- Retaining the copyright to your article

Submit your next manuscript at $>$ springeropen.com 